\title{
A Review on Perspective Impact of Egg Shell Powder on Durability Behavior of Cement Concrete
}

\author{
S. Deepak ${ }^{1 *}$, K. Sargunan ${ }^{2}$ \\ ${ }^{I} P G$ Student, KSR College of Engineering, Tiruchengode, Namakkal. Tamil Nadu, India. \\ ${ }^{2}$ Assistant professor KSR College of Engineering, Tiruchengode, Namakkal, Tamil Nadu, India. \\ *Corresponding author E-Mail ID: deepalksr@gmail.com \\ Doi: https://doi.org/10.34256/irjmtcon54
}

\begin{abstract}
Dumping of organic waste products without knowing their ideals of other side causes major and various serious environmental degradation problems. In this forum, this paper is mainly focuses on reviewing various eggshell material related research articles published in past years from 20102019 in several reputed journals. Various cement concrete material investigations which are partially proportioned with chicken egg shell powder are taken into consideration probably in line with durability study aspects like corrosion resistance. And their outcomes are listed in a way of positive stroke. Chicken egg shell are one of the wastes typically dumped in the ground produces the greenhouse gas emission, ground water contamination etc. Though chicken egg shell powder by raw consists of $94-95 \%$ of calcium carbonate $(\mathrm{CaCo3})$ and on incineration turns to calcium oxide $(\mathrm{CaO})$. The use of egg shell in replacement of cement in concrete can have benefits like minimizing use of cement instead of using natural lime. Usually soon after the construction process, the reinforcements got rusted (its volume bulges) and it leads to cracks in the wall and reduces the life of the concrete structure. The one of the reasons cracks produce due to the corrosion of steel in the concrete. That leads to the reducing in strength of the reinforcement bars and cracks formed in the concrete. With respect to the reviews made utilization of egg shell powder in concrete by replacement of cement to a limit which reacts as an economical corrosion resistive product.
\end{abstract}

\section{Keywords: Egg Shell Powder, Cement Concrete, Concrete mixtures,}

\section{INTRODUCTION}

The concrete has been widely used for the construction of most of the buildings, bridges and more. Concrete plays a vital role in construction. Most of the researches had proved that replacement of mixtures in concrete produce a more workable building material. Most of the wastes like plastics, papers, organic wastes etc. It can be recycled in the concrete to attain more strength, durability. The egg shells are one of the waste derivatives from hotels, bakeries, and hatchery units which are usually dumped in the open ground without considering its ill effects. The beneficiary sides of egg shells are not taken in to account for disposing it by end consumers.

Nowadays the need and scarcity of raw materials for cement production pertains to various ideal investigations with the use of alternatives for binder. The egg shell contains calcium carbonate in it. The word "concrete" is derived from the Latin word concretus, meaning "to grow together". In that reinforcement are the back bone of concrete which they give more strength and durability to the concrete. 


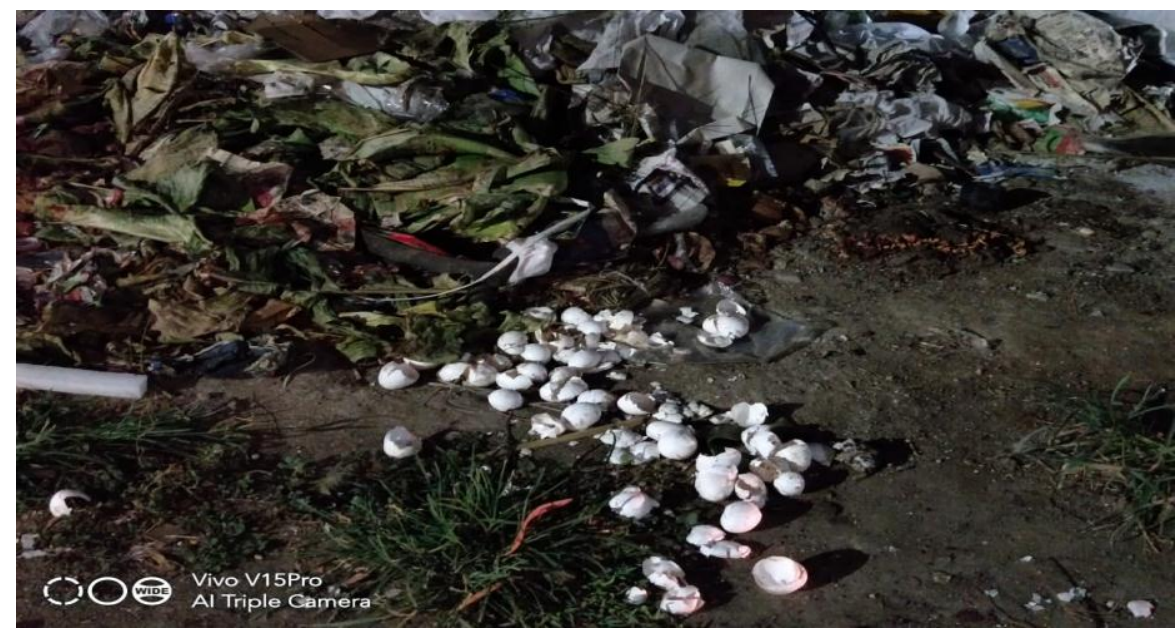

Fig 1. Waste egg shells

\section{LITERATURE REVIEW}

Mtallib et al. (2009) investigated on effects of incinerated egg shell powder on the setting time of cement. The shells are powdered and incinerated and the ash was sieved in $75 \mu \mathrm{m}$. The substitute of ESA by $0 \%, 0.1 \%, 1 \%, 1.5 \%, 2 \%$ and $2.5 \%$ weight of cement. This process shows that substitute of ESA to OPC increases the setting time of cement. Thus the ESA is used as an accelerator.[1]

Jayashankar et al. (2010) investigated on properties of concrete by partial replacing of rice husk, fly ash and egg shell powder to cement. The different mix designs were used M20, M25 and M30. The mixing percentage substitutes of 5\%,10\%, 15\% and 20\%. The result shows that RHA, ESP and FA cube are added with M25 strength is decreased. [2]

Siti Fatimah Abdul et al. (2012) investigated on embedded capacitor sensor for monitoring corrosion of reinforcement concrete. The corrosion in reinforcement cause cracking of concrete and it not been viewed so the sensor capacitor has embedded. The sensors were tested in acid and alkali solutions using Agilent 4284 Precision LCR meter. The specimens were exposed to environment. At finally corrosion has been found in the broken specimen and also the corrosion activity is noted by the sensors. [3]

Gowsika et al. (2014) investigated on partial replacement of egg shell powder with cement concrete in the mixing of cement mortar in ratio 1:3 to determine the chemical composition and compressive strength. The cement is partially replaced with egg shell powder as $5 \%, 10 \%, 15 \%$, $20 \%, 25 \%$ and $30 \%$ by weight of cement. At the age of 28 th day the compressive strength was determined. At the various replacements of egg shell powder and micro silica gives different strength at different aspects. [4]

DohShuIng et al. (2014) investigated on potential addictive as egg shell powder to concrete. The egg shell powder is used in different percentages replacement of cement. The concrete mix of grade M25 is used in it. At the 10\% of replacement of egg shell powder the maximum strength and compressive strength is increased. And the flexural strength also increase and water absorption and bending failure also improved. [5]

TarekUddin Mohammed et al. (2015) investigated on corrosion of steel bars in concrete. The corrosion of steel in marine area, hence the steel bars are coated with cement paste of different water cement ratio. The cylinder concrete specimens were made and the cement paste with water cement ratio of $0.3,0.5,0.7$ and 1.0. The specimens were tested accelerated sea water in wetting and drying by 45 cycles in the environment. The cement paste coating in the steel rods 
by mixing with low water cement ratio prevents the formation of corrosion in high level chloride content. [6]

Dhanalakshmi et al. (2015) investigated on experimental study of egg shell with partial replacement of fly ash. These used to know the various properties like compressive strength, workability and flexural strength. The fly ash is added to the optimum level of egg shell powder and is varies upto $12.5 \%$. The result says that $7.5 \%$ of egg shell powder substitution gives good compressive strength and split tensile strength. And the egg shell powder is mixed with fly ash gives less compressive strength. [7]

Soumyan et al. (2016) investigated on the effect of rise hush ash and the egg shell powder on the concrete. The partial replacement of cement by RHA and ESP reduce the consumption of cement. The mixing of the mortar at 1:1.5:3 and the specimen tested at the age of 28 days. Thus the substituted material of rise husk and egg shell gives more strength than the conventional concrete. [8]

Pedro Castro-Borges et al. (2017) investigation on corrosion rate for Reinforced concrete in tropical natural marine environment. The study is on corrosion levels of steel in concrete at different stages of corrosion layers and formation of cracks. At $50 \mathrm{~m}$ from the seashore sixty Portland cement concrete cylinders were exposed. The corrosion rate was measured by linear polarization resistance technique. The result shows that the technique not only measures the initial stage of corrosion and also the corrosion performance. [9]

TutyAsma Abu Bakar et al. (2017) investigation on egg shell coated grey cast iron for corrosion applications. The egg shell has been coated on the grey cast iron substrate in condition of $80 \mathrm{v}$ for a minute at temperature of 600 degree Celsius. The investigation shows that the egg shell coating is the good corrosion resistance.[10]

Deepika et al. (2017) investigated on the replacement of egg shell powder and also incinerated egg shell powder. The incinerated egg shell powder is $30 \%$ is used in the replacement of cement and the egg shell powder $20 \%$ is used in replacement of cement. The durability tests are conducted in this process. The durability of incinerated egg shell powder is increased. [11]

Parvathy et al. (2018) investigated on the study of durability aspects of high strength concrete using fly ash and alcofline. In this concrete cement is partially replaced with $30 \%$ fly ash and alcofline of grade1203 and the plasticizers are used in it for greater workability. The M60 grade specimens are used in the concrete. The rapid chloride penetration test were conducted, water absorption test, carbonation test and water permeability tests also been conducted. All the tests proved that the concrete are more durability than the conventional concrete. [12]

Vijayvenkatesh et al. (2018) investigated on partial replacement of cement with egg shell and glass powder. The concrete cube is casted at standard size and tested on 7 days, 14 days and 28 days interval. The partial replacement of egg shell ash powder and glass powder for the cement by $20 \%, 30 \%$ and $40 \%$. The M20 grade is used and attains good compressive strength and tensile strength at the $28^{\text {th }}$ day at $20 \%$ and $30 \%$. And it is optimum and recommended for structural purpose. [13]

TerroLuukkonen et al. (2018) Alkali-activated materials are used as alternative for the OPC that also prevents emission of $\mathrm{CO}_{2}$ gas in the environment. These are difficult to handle hence concentrated aqueous solutions are corrosive. The aluminosilicate precursor is one of the parts in it that are similar to OPC preparation. It is suitable for PCC structures and for RCC this process cannot be used due to the aqueous solution and it leads to corrosion. [14]

Omprakash et al. (2018) investigation on experimental study of strength properties of concrete using GGBS, rice husk ash and egg shell powder. As all the egg shell powder contains more calcium carbonate content. In many hotels egg shells are dumped in the garbage without 
knowing the worth of it. The GGBS and rice husk is mixed at five distinct contents of $0 \%, 5 \%$, $10 \%, 15 \%$ and $20 \%$ substitute of cement in terms of weight and $5 \%$ egg shell powder is added at every substitutions. The OPC ofgrade 53 is used in it. The investigation proves that GGBS with egg shell powder increases the compression strength compare to conventional concrete $20 \%$ and rice husk ash with ESP increase in compressive strength by $15 \%$ than conventional concrete. [15]

Hyun-Jin Yu et al. (2019) investigated on cyclic loading test of structural walls with small openings. The load is considered on five RC walls with an aspect ratio of 2.6 and small openings in it. The tests show that the small openings did not affect the deformation capacity and the flexural strength if the small openings away from the compressive area and walls have sufficient shear resistance. [16]

\section{CRITICAL REMARKS}

The usage of incinerated egg shell powder and egg shell powder with cement concrete as a substitute for binder to certain dosage can possibly reduce the production quantity and environmental effects vice versa. Durability of the concrete can be increased and it also directs the usage of egg shells among the environment.

1. The substitute of ESA to OPC increases the setting time of cement. Thus it is used as an accelerator.

2. Egg shell powder is used as a partial replacement of cement and it yields more strength than conventional concrete.

3. $7.5 \%$ of egg shell powder substitution gives good compressive strength and split tensile strength

4. Rice husk is used as filler in concrete not as a replacement of cement content in concrete and Alkali activated materials like concentrated aqueous solution are capable for PCC but not capable for RCC due to the corrosion level of the solution.

5. The M20 grade concrete with egg shell ash replacement attains good compressive strength and tensile strength at the 28th day at $20 \%$ and $30 \%$

6. The replacement of cement by $15 \%$ ESP increase the compressive strength and more than $15 \%$ ESP leads to decrease in strength.

7. Egg shell powder is supremacy in its economical point also.

8. Moreover ESP is a good corrosion resistance material and even it increases the durability of concrete better than the conventional one.

\section{REFERENCE}

1. Vijayvenkatesh Chandrasekaran, Vasanth M, Thirunavukkarasu S and Manikanda Prabu T, "Experimental investigation of Partial Replacement of Cement with Glass Powder and Eggshell Powder Ash in Concrete" Civil Engineering Research Journals, Volume 5 Issue 3June 2018.

2. TeroLuukkonena, Zahra Abdollahnejada,JuhoYliniemia, PaivoKinnunena,b and MirjaIllikainena "One-part alkali-activated materials: A review" Cement and Concrete research.

3. D.Gowsika, S.Sarankokila, K.Sargunan, "Experimental Investigation of Egg Shell Powder as Partial Replacement with Cement in Concrete" International Journal of Engineering Trends and Technology (IJETT) - Volume 14 Number 2 - Aug 2014. 
4. Hyun-Jin $\mathrm{Yu}, \mathrm{Su}-\mathrm{Min}$ Kang, Hong-Gun Park and Lan Chung, "Cyclic Loading Test of Structural Walls with Small Openings"'International Journal of Concrete Structures and Materials.

5. TarekUddin Mohammed1, Hidenori Hamada, ArifulHasnat and Mohammed Abdullah Al Mamun "Corrosion of Steel Bars in Concrete with the Variation of Microstructure of SteelConcrete Interface” Journal of Advanced Concrete Technology Vol. 13, 230-240, April 2015.

6. Pedro Castro-Borges, Mercedes Balancán-Zapata, and Alexia Zozaya-Ortiz, “Electrochemical Meaning of Cumulative Corrosion Rate for Reinforced Concrete in Tropical Natural Marine Environment"Hindawi Advances in Materials Science and Engineering Volume 2017, Article ID 6973605, 8 pages.

7. Siti Fatimah Abdul Rahman, Mohammad Ismail,Norhazilan MD. Noor, HazriBakhtiar, "Embedded Capacitor Sensor For Monitoring Corrosion Of Reinforcement In Concrete" Journal of Engineering Science and Technology Vol. 7, No. 2 (2012) 209 - 218.

8. K. Omprakash, K. Jaya Chandra, B. BalakrishnaBharath, "An experimental Study of Strength Properties of Concrete Using GGBS, Rice Husk Ash and Egg Shell Powder" International Journal of Scientific Research and Review.

9. TutyAsma Abu Bakar, Muhammad FadzilRosly, NurSyairahtulAinMohamadJafar, "Egg Shell Coated Grey Cast Iron for Corrosion Applications" JurnalTeknologi

10. Jayasankar.R, Mahindran.N , Ilangovan.R, "Studies on Concrete using Fly Ash, Rice Husk Ash and Egg ShellPowder”'International Journal Of Civil Engineering, Volume 1, No 3, 2010.

11. Dhanalakshmi M, DrSowmya N J, DrChandrashekar A, “A Comparative Study on Egg Shell Concrete withPartial Replacement of Cement by Fly Ash" International Journal for Research in Applied Science \& EngineeringTechnology (IJRASET), Volume 3, Special Issue-I1, June 2015.

12. DOH ShuIng, CHIN SiewChoo, "Eggshell Powder: Potential Filler in Concrete" Faculty of Civil Engineering and Earth Resources, University Malaysia Pahang LebuhrayaTunRazak, 26300 Gambang, Kuantan Pahang.

13. T.Deepika, N.Gobinath, M.Tigerprabakaran, "Durability Study Of Concrete With Egg Shell Powder" International Journal of Advanced Science and Engineering Research, Volume: 2, Issue: 2, June 2017.

14. M.O.A. Mtallib and A. Rabiu, "Effects OfEgg Shell Ash on The Setting Time of Cement" Department of Civil Engineering Bayero University, Kano.

15. Soumyan K, AswathiVishwanath k, "Experimental Study to Check the Effect of Egg Shell Powder and Rice Husk Ash on the Property of Concrete” International Journal of Engineering Research \& Technology (IJERT) - 2016.

16. A. ParvathyKarthika, V. Gayathri, "Experimental Studies on Durability Aspects of High Strength Concrete using Flyash and Alccofine”, International Journal of Recent Technology and Engineering (IJRTE) Volume-7 Issue-4S, November 2018 